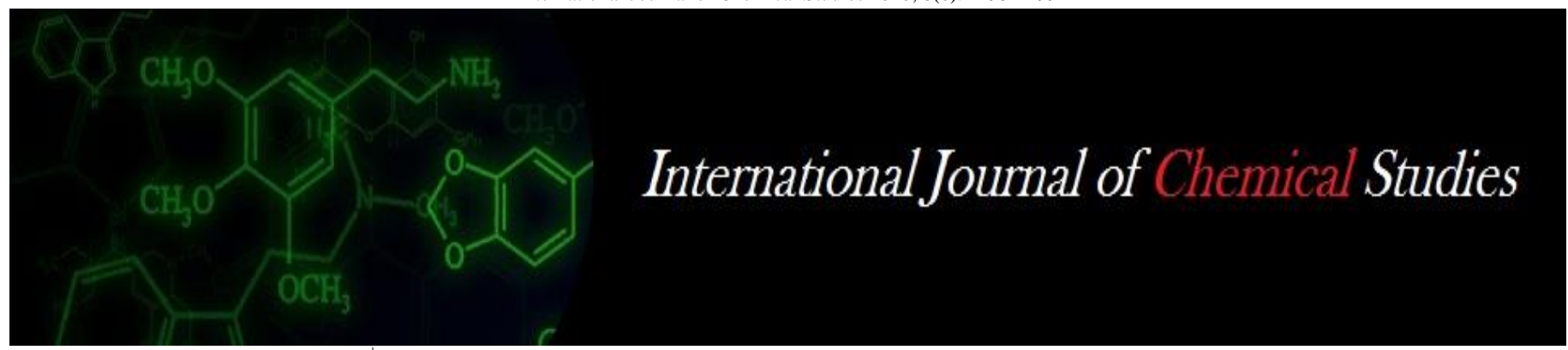

P-ISSN: 2349-8528

E-ISSN: 2321-4902

www.chemijournal.com

IJCS 2020; 8(6): 2493-2499

(C) 2020 IJCS

Received: 04-09-2020

Accepted: 09-10-2020

\section{RR Dhutmal}

Sorghum Research Station,

Vasantrao Naik Marathwada

Krishi Vidyapeeth, Parbhani,

Maharashtra, India

Ambika More

Sorghum Research Station,

Vasantrao Naik Marathwada

Krishi Vidyapeeth, Parbhani,

Maharashtra, India

NE Jayewar

Sorghum Research Station,

Vasantrao Naik Marathwada

Krishi Vidyapeeth, Parbhani,

Maharashtra, India
Corresponding Author: RR Dhutmal

Sorghum Research Station,

Vasantrao Naik Marathwada

Krishi Vidyapeeth, Parbhani,

Maharashtra, India

\section{Current status and future prospects of millets with special reference to sorghum (Sorghum bicolor Moench (L.)}

\author{
RR Dhutmal, Ambika More and NE Jayewar
}

DOI: https://doi.org/10.22271/chemi.2020.v8.i6aj.11146

\section{Abstract}

Millets are not only comparable to major cereals with respect to their nutritional features but are very good sources of carbohydrates, micronutrients and phytochemicals with nutraceutical properties. The millets contain $7-12 \%$ protein, $2-5 \%$ fat, $65-75 \%$ carbohydrates and $15-20 \%$ dietary fibre. Sorghum has 11.9 per cent of moisture and about 10.4 per cent of protein and a lower fat content of 1.9 per cent. The fibre and mineral content of grain sorghum is essentially similar, and is 1.6 per cent. It is a good source of energy and provides about $349 \mathrm{~K}$ cal and gives 72.6 per cent of carbohydrates. The nature and utilization of sorghum grain has undergone a change from staple food to industrial uses such as livestock and poultry feed, potable alcohol, starch and ethanol production, however, grain as a whole consumption declining with the falling production figures with an annual growth rate of around $-2.06 \%$. Most of the sorghum consumed by human comes from post rainy sorghum nearly $90 \%$ of the toal production) and remaining $10 \%$ goes to the processing sector. Kharif sorghum after meeting 40-45\% consumption demand left over surplus production is diverted to industries. As far as sorghum processing is concerned, majority of the processing is done as sorghum floor which is done at individual level. While for other processed products such as, biscuits, rawa, multigrain flour and biscuits an increasing interest and trend is observed in last few years. In future collaboration with private companies and cooperative sector may took a lead for such processed products and required infrastructures. Sorghum is not yet included in Public Distribution System, its inclusion may enhance the area under kharif as well as Rabi sorghum.

Keywords: Current, future prospects, sorghum, Sorghum bicolor

\section{Introduction}

Importance of millets

Sorghum and millets namely, Pearl millet, Finger millet, Kodo millet, Proso millet, Foxtail millet, little millet, and Barnyard millet are important staples to millions of people world-wide. Millets are a group of gluten-free cereal grains that are highly nutritious and commonly contain higher protein, minerals, vitamins and fiber levels, compared to corn, rice and wheat. Millets can be grown with little water compared to most other grains and are very well suited to drought-like conditions. They form grains in 90-110 days and are often cultivated on skeletal soils. Millet production is traditionally not dependent on the use of synthetic fertilizers and a majority of them are not affected by storage pests. Additionally, great natural biodiversity exists in millets, hence making them amenable to cultivation in various agroclimatic conditions.

In this age of modern life style, the millets and millet foods are gaining good response due to various health advantages. Demand is growing for highly nutritional and balanced diet due to health awareness in today's ever changing world. It is time to develop a holistic approach to strengthen the resilience of agricultural livelihoods through the new initiative of promoting nutritious and hardy traditional climate smart millet crops to strengthen the resilience of food systems. These magic minor millets have the significant value in the context of India, as a large section of its population still depends on the production and productivity of millets and other so-called minor crops." Drawing on ethnographic evidence collected through field research generations together the "millets" were the daily staple food for the people of India. Then, they almost totally eschewed millets in favor of polished white rice and wheat, as the latter became more accessible. 
Yet in the past few years, public health and development professionals have launched efforts to re-popularize millets as neglected and underutilized species that have the potential to positively affect consumer nutrition, use of environmental resources and livelihood stability.

Millets are not only comparable to major cereals with respect to their nutritional features but are very good sources of carbohydrates, micronutrients and phytochemicals with nutraceutical properties. The millets contain $7-12 \%$ protein, $2-$ $5 \%$ fat, $65-75 \%$ carbohydrates and $15-20 \%$ dietary fibre. Among them, pearl millet contains considerably high proportion of proteins (12-16\%) as well as lipids (4-6\%) whereas; finger millet contains lower levels of protein $(6-8 \%)$ and fat $(1.5-2 \%)$. The essential amino acid profiles of the millet protein is better than maize. The niacin content in pearl millet is higher than all other cereals whereas, finger millet proteins are unique because of the sulphur rich amino acid contents. Similar to cereal proteins, the millet proteins are poor sources of lysine, but they complement well with lysine- rich vegetable (leguminous) and animal proteins form nutritionally balanced composites of high biological value. Small millets are more nutritious compared to fine cereals. Finger millet is the richest source of calcium (300-350 $\mathrm{mg} / 100 \mathrm{~g}$ ) and other small millets are good source of phosphorous and iron.

Sorghum has 11.9 per cent of moisture and about 10.4 per cent of protein and a lower fat content of 1.9 per cent. The fibre and mineral content of grain sorghum is essentially similar, and is 1.6 per cent. It is a good source of energy and provides about $349 \mathrm{Kcal}$ and gives 72.6 per cent of carbohydrates (Gopalan et al., 1996) ${ }^{[9]}$. Starch is the major carbohydrate of the grain. The other carbohydrates present are simple sugars, cellulose and hemicellulose. The amylose content of starch varies from 21.28 per cent. Sorghum is also rich in dietary fibre $(14.3 \%)$. Calcium, phosphorous and iron content of sorghum is $25 \mathrm{mg}, 222 \mathrm{mg}$ and $4.1 \mathrm{mg}$ (per $100 \mathrm{~g}$ of edible portion), respectively (Hosmani and Chittapur, 1997) ${ }^{[11]}$.

Table 1: Nutrient content of various millets with comparison to rice and wheat

\begin{tabular}{|c|c|c|c|c|c|}
\hline Crop & Protein (\%) & Fibre (\%) & Mineral (\%) & Iron (mg/100g) & Calcium (mg/100g) \\
\hline Sorghum & 11.6 & 1.6 & 1.6 & 2.2 & 25 \\
\hline Finger millet & 7.3 & 3.6 & 2.7 & 3.9 & 344 \\
\hline Pearl millet & 10.6 & 1.3 & 2.3 & 16.9 & 38 \\
\hline Foxtail millet & 12.3 & 8 & 3.3 & 2.8 & 31 \\
\hline Kodo millet & 8.3 & 9 & 2.6 & 0.5 & 17 \\
\hline Little millet & 7.7 & 7.6 & 1.5 & 9.3 & 17 \\
\hline Proso millet & 12.5 & 2.2 & 1.9 & 0.8 & 11 \\
\hline Barnyard millet & 11.2 & 10.1 & 4.4 & 0.7 & 10 \\
\hline Rice & 6.8 & 0.2 & 0.6 & 5.3 & \\
\hline Wheat & 11.8 & 1.2 & 1.5 & & \\
\hline
\end{tabular}

Source: National Institute of Nutrition (NIN), Hyderabad The current scenario regarding cultivation, consumption marketing mechanism and demand supply position of millets
Current scenario regarding cultivation

Table 2: Sorghum performance in major producing states (A-m ha; $\mathrm{P}-\mathrm{m}$ tons and $\mathrm{Y}-\mathrm{kg} / \mathrm{ha}$ )

\begin{tabular}{|c|c|c|c|c|c|c|c|c|c|c|c|c|c|c|c|}
\hline \multirow{2}{*}{ State } & \multicolumn{3}{|c|}{$1966-1968$} & \multicolumn{3}{|c|}{ 1976-1978 } & \multicolumn{3}{|c|}{ 1986-88 } & \multicolumn{3}{|c|}{ 1996-1998 } & \multicolumn{3}{|c|}{ 2008-2010 } \\
\hline & Area & Prod & Yield & Area & Prod & Yield & Area & Prod & Yield & Area & Prod & Yield & Area & Prod & Yield \\
\hline Andhra Pradesh & 2.57 & 1.24 & 483 & 2.21 & 1.31 & 587 & 1.51 & 0.87 & 568 & 0.80 & 0.56 & 695 & 0.30 & 0.39 & 1304 \\
\hline Gujarat & 1.31 & 0.35 & 264 & 1.03 & 0.57 & 553 & 0.73 & 0.27 & 354 & 0.29 & 0.25 & 862 & 0.15 & 0.17 & 1119 \\
\hline Karnataka & 2.82 & 1.49 & 527 & 2.00 & 1.62 & 808 & 2.40 & 1.71 & 710 & 1.92 & 1.60 & 833 & 1.33 & 1.49 & 1129 \\
\hline Mah & 6.25 & 3.35 & 535 & 6.53 & 4.90 & 750 & 6.39 & 4.44 & 691 & 5.32 & 4.83 & 908 & 4.10 & 3.53 & 862 \\
\hline & 1.08 & 0.32 & 294 & 0.79 & 0.32 & 408 & 1.01 & 0.34 & 334 & 0.57 & 0.24 & 410 & 0.67 & 0.31 & 474 \\
\hline Madhya Pradesh & 2.43 & 1.75 & 725 & 1.91 & 1.34 & 700 & 1.88 & 1.56 & 835 & 0.84 & 0.75 & 894 & 0.45 & 0.58 & 1295 \\
\hline
\end{tabular}

Source: Directorate of Economics \& Statistics

The details of sorghum performance in major producing states are summarized in Table 2. The area under Maharashtra has declined from $6.25 \mathrm{~m}$ ha in 1966-68 to $4.10 \mathrm{~m}$ ha in $2008-10$. The production was much stable and productivity has increased significantly $(61 \%)$ during the same period. Karnataka exhibited similar trend in area and production whereas the productivity has improved drastically (114\%). Andhra Pradesh lost both area and production considerably but the mean yields have increased reasonably (170\%). Gujarat almost followed the similar path of Andhra Pradesh during study period. Rajasthan also lost sorghum area appreciably between 1966 and 2010. In case of Madhya Pradesh, the cropped area has declined significantly to 20 per cent and production to one-third between 1966 and 2010. But, the productivity registered a substantial improvement from 725 to $1295 \mathrm{~kg}$ per ha.

Table 3: Area production and productivity of kharif sorghum pertaining to Marathwada and Maharashtra (Area in lakh ha, production in lakh tones and productivity $\mathrm{kg} / \mathrm{ha}$ )

\begin{tabular}{|c|c|c|c|c|c|c|}
\hline \multirow{2}{*}{ Sr. No. } & \multirow{2}{*}{ Year } & \multirow{2}{*}{ A/P/Y } & \multicolumn{2}{|c|}{ Kharif sorghum } & \multicolumn{2}{c|}{ Rabi sorghum } \\
\cline { 3 - 7 } & & & Marathwada & Maharashtra & Marathwada & Maharashtra \\
\hline \multirow{3}{*}{1} & \multirow{2}{*}{$2012-13$} & Area & 3.30 & 7.60 & 8.64 & 22.78 \\
\cline { 3 - 7 } & & Production & 3.97 & 10.40 & 5.45 & 4.19 \\
\cline { 3 - 7 } & Productivity & 1203 & 6.18 & 7.67 & 22.40 \\
\hline \multirow{3}{*}{2} & \multirow{2}{*}{$2013-14$} & Area & 2.52 & 7.58 & 6.70 & 17.80 \\
\cline { 3 - 7 } & & Production & 3.20 & 1226 & 874 & 795 \\
\cline { 3 - 7 } & & Productivity & 1270 & &
\end{tabular}




\begin{tabular}{|c|c|c|c|c|c|c|}
\hline \multirow{3}{*}{3} & \multirow{3}{*}{ 2014-15 } & Area & 3.66 & 6.80 & 8.28 & 26.0 \\
\hline & & Production & 197 & 5.84 & 3.74 & 15.24 \\
\hline & & Productivity & 539 & 860 & 455 & 584 \\
\hline \multirow{3}{*}{4} & \multirow{3}{*}{$2015-16$} & Area & 2.97 & 6.21 & 8.80 & 25.97 \\
\hline & & Production & 1.09 & 3.68 & 2.52 & 8.37 \\
\hline & & Productivity & 369 & 594 & 285 & 322 \\
\hline \multirow{3}{*}{5} & \multirow{3}{*}{ 2016-17 } & Area & 2.89 & 6.04 & 11.79 & 30.12 \\
\hline & & Production & 1.66 & 5.75 & 9.27 & 19.63 \\
\hline & & Productivity & 549 & 953 & 808 & 652 \\
\hline \multirow{3}{*}{6} & \multirow{3}{*}{ 2017-18 } & Area & $*$ & 4.10 & $*$ & 17.60 \\
\hline & & Production & $*$ & 4.17 & $*$ & 13.90 \\
\hline & & Productivity & $*$ & 1018 & $*$ & 790 \\
\hline
\end{tabular}

Area under Kharif sorghum in Maharashtra state was 7.60 lakh ha. In 2012-13 and declined to 4.17 lakh ha (2017-18). While in Marathwada it declined from 3.30 lakh ha (2012-13) to 2.89 lakh ha (2016-17). Productivity of Kharif sorghum is decreased from $1368 \mathrm{~kg} / \mathrm{ha}(2012-13)$ to $1018 \mathrm{~kg} / \mathrm{ha}(2017-$ 18) in state. In Marathwada region, productivity was drastically decreased from $1203 \mathrm{~kg} / \mathrm{ha}(2012-13)$ to $549 \mathrm{~kg} / \mathrm{ha}$ (2016-17).

Area under Rabi sorghum in state was 22.78 lakh ha in 201213 and gradually decline to 17.60 lakh ha (2017-18). While in Marathwada is constant from 8.64 (2013.13) to 8.80 (201516). But productivity of Rabi sorghum is increased by $2-3$ times from $404 \mathrm{~kg} / \mathrm{ha}(2012-13)$ to $790 \mathrm{~kg} / \mathrm{ha}$ (2017-18). In Marathwada it was increased from $515 \mathrm{~kg} / \mathrm{ha}$ (2012-13) to $808 \mathrm{~kg} /$ ha (2016-17). Increase in productivity of Rabi sorghum is mainly due to development of improved varieties, adoption of improved crop management technologies with better soil moisture conservation techniques. Rabi sorghum area decline through at lower magnitude in Maharashtra \& Marathwada.

Unlike Kharif sorghum, the Rabi sorghum had no marketing problems and most of the produce is consumed by the farmers themselves or in the nearby town and cities. Due to its terminal drought tolerance, Rabi sorghum is fairly competitive with maize. The high biomass productivity potential of sorghum under moisture stress gives it an edge over other crops, as fodder supply is critical during dry season.

\section{Consumption}

In the last two decades the nature and utilization of sorghum grain has undergone a change from staple food to industrial uses such as livestock and poultry feed, potable alcohol, starch and ethanol production (Kleih et al., 2000) ${ }^{[10]}$. Additionally, new value added/processed food products for human consumption are emerging such as popped sorghum, papad, porridge, rava and as an ingredient for Indian dishes like dosa, khichdi etc. which are, though in the nascent stage, are likely to be significant avenues for diversifying utilization trends of sorghum. In India, consumption is more or less analogous to the production trend. However, grain as a whole consumption declining with the falling production figures with an annual growth rate of around $-2.06 \%$ (see Fig 3)

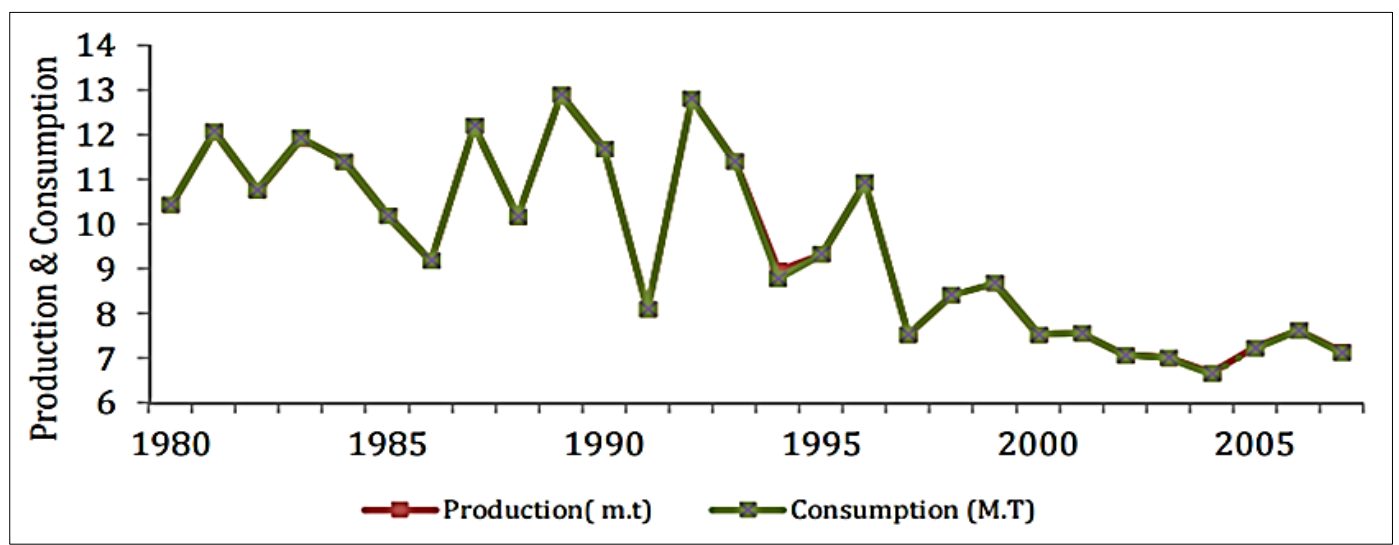

Source: CRP 3.6 Dryland Cereal Proposal, ICRISAT dated August 162012

Fig 1: Sorghum production and consumption in India

Annual per capita consumption of sorghum at all India level has declined by $68 \%$ from $8.5-2.7 \mathrm{~kg}$ in urban areas and by $70 \%(19.1-5.2 \mathrm{~kg})$ in rural areas. The decline is due to increase in per capita income, growing urbanization and changing tastes and preferences (Ramesh Chand, 2007) ${ }^{[3]}$. Maharashtra has highest per capita annual consumption of 54 $\mathrm{kg}$ in rural areas and $34 \mathrm{~kg}$ in urban area (Basavraj et al. 2011 \& 2012) ${ }^{[2]}$. Most of the sorghum consumed by human comes from post rainy sorghum nearly $90 \%$ of the total production) and remaining $10 \%$ goes to the processing sector. Kharif sorghum after meeting 40-45\% consumption demand left over surplus production is diverted to industries (Dayakar Rao et al., 2010) ${ }^{[5,10]}$.

\section{Marketing mechanism}

Grain sorghum when molded and deteriorated fetches poor market price. Sorghum lacks organized trade and processing as a food before it reaches consumers. Recently efforts were made by Govt. of India and Directorate of Marketing in evolving grades and standard which would pave a way for organized trading. Currently majority of the produce is marketed in local markets.

Less than $10 \%$ sorghum grain, flow through the regulated market while the bulk quantity is routed through nonregulated market channels. In addition to this Hurda sorghum having comparatively higher economic importance is mainly marketed by retailed outlets, hotels and supply to malls etc. 
Although sorghum and pearl millets are primarily grown for domestic consumption, a significant portion of production is traded. This is particularly true for rainy season sorghum and pearl millets which are increasingly being used in the poultry and cattle feed industry and in the manufacture of fine grain alcohol. However, the markets are dominated by middlemen reducing the farmers share in consumer rupee. There is need for innovative models linking farmers to end users that would reduce transaction and marketing costs for both the farmers and the buyers.

Fodder markets are informal and there is no regulation on the sales and purchases. The transactions are generally carried out by middlemen who play an important role in determining the price. Although the demand for processed (chopped) fodder is increasing, there are no policies incentives for private fodder processing.

Demand supply position of sorghum

Table 4: Projected cereal supply, demand and net trade, India, 1995 and 2020

\begin{tabular}{|c|c|c|c|c|c|c|}
\hline \multirow{3}{*}{ Year/Cereal } & \multicolumn{3}{|c|}{ Declining productivity growth net } & \multicolumn{3}{|c|}{ Sustained productivity growth net } \\
\hline & Supply & Demand & Exports & Supply & Demand & Exports \\
\hline & & & \multicolumn{2}{|c|}{ (million metric tons) } & & \\
\hline \multicolumn{7}{|c|}{1995} \\
\hline Rice & 79.5 & 77.5 & 2.0 & 79.8 & 77.5 & 2.3 \\
\hline Wheat & 59.7 & 63.5 & -3.8 & 60.0 & 63.5 & -3.5 \\
\hline Coarse grains & 32.7 & 39.7 & 3.0 & 32.9 & 29.7 & 3.2 \\
\hline Total cereals & 171.9 & 170.7 & 1.2 & 172.7 & 170.7 & 2.0 \\
\hline \multicolumn{7}{|c|}{2020} \\
\hline Rice & 120.5 & 124.5 & -4.0 & 134.0 & 124.5 & 9.5 \\
\hline Wheat & 107.6 & 111.0 & -3.4 & 127.3 & 111.0 & 16.3 \\
\hline Coarse grains & 42.3 & 57.9 & -15.6 & 48.0 & 57.9 & -9.9 \\
\hline Total cereals & 270.4 & 293.4 & -23.0 & 309.3 & 293.4 & 15.9 \\
\hline
\end{tabular}

The trend of falling area and production of sorghum are continuing in India and Maharashtra even after 2011. So its supply is further projected to decrease in the future also. According to IFPRI-ICAR projections the demand for sorghum is expected to increase from $29.7 \mathrm{~m}$ tones in 1995 to about $57.9 \mathrm{~m}$ tones in 2020. The shares of feed and other uses are projected to increase slowly.

Productivity of existing varieties, status of adaption of modern cultivation technology and yield gap analysis

Table 5: Productivity of existing varieties

\begin{tabular}{|c|c|}
\hline Existing varieties & Productivity (q/ha) \\
\hline \multicolumn{2}{|c|}{ Kharif varieties } \\
\hline Parbhani Shweta (PVK 801) & 28.0 \\
\hline PVK 809 & 30.0 \\
\hline Parbhani Shakti (PVK 1009) & $35.0-38.0$ \\
\hline \multicolumn{2}{|c|}{ Kharif hybrids } \\
\hline CSH 14, CSH 16, CSH 23 & $38-42$ \\
\hline SPH 1641 Rabi varieties \\
\hline Parbhani Moti & 45.0 \\
\hline Phule Vasudha & $18.0-$ RF, 28.0-IR \\
\hline Akola kranti & $20-22$ \\
\hline
\end{tabular}

Status of adaption of modern cultivation technology

Table 6: Pattern of varietal replacement in major states by release year

\begin{tabular}{|c|c|c|c|c|c|c|}
\hline \multirow{2}{*}{ Released years } & \multicolumn{2}{|c|}{ Andhra Pradesh } & \multicolumn{2}{c|}{ Maharashtra } & \multirow{2}{*}{ Madhya Pradesh (Kharif) } & \multirow{2}{*}{ Rajasthan (Kharif) } \\
\cline { 2 - 5 } & Kharif & $\boldsymbol{R} \boldsymbol{a b i}$ & Kharif & $\boldsymbol{R a b i}$ & 0 & 0 \\
\hline $1960-70$ & 0 & 10 & 0 & 20 & 0 & 3 \\
\hline 197040 & 0 & 0 & 0 & 0 & 0 & 4 \\
\hline $1980-90$ & 0 & 10 & 15 & 0 & 77 & 11 \\
\hline $1991-00$ & 38 & 30 & 45 & 1 & 0 & 0 \\
\hline $2001-10$ & 2 & 0 & 20 & 29 & 0 & 35 \\
\hline Period unknown & 0 & 0 & 20 & 0 & 77 & 17 \\
\hline \% area under MVs & 40 & SO & 100 & 50 & & \\
\hline
\end{tabular}

The patterns of varietal replacement by their age are summarized in Table 6 for major sorghum growing states in India. In general, the initial results are comparable with secondary information collected from respective state agricultural departments and state seed corporations. Overall, the cultivars released during 1990-2000 were occupied major shares of cropped areas in different states (Directorate of Economics and Statistics, Government of India). 


\section{Yield gap analysis}

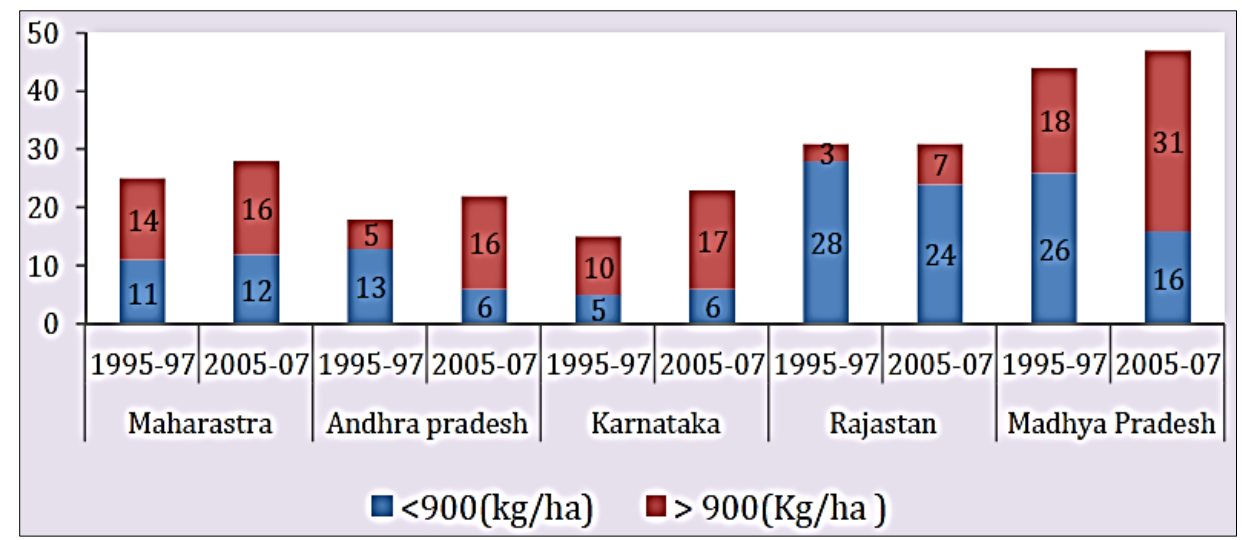

Source: District level data base, ICRISAT

Fig 2: District wise sorghum gaps

Thorough analysis of District Level Data (DLD) in five major sorghum growing states (Maharashtra, Andhra Pradesh, Karnataka, Rajasthan, Madhya Pradesh) reveals interesting results on yield performances (Fig 2). Out of the total no. of districts data available (185), only 133 and 151 districts have grown sorghum respectively during 1995-97 and 2005-07 study periods. A comparison was made and classified the total no. of sorghum growing districts based on mean country productivity of $900 \mathrm{~kg}$ per ha. Further the details of the analysis have been summarized in Fig 12. It clearly shows that out of 133 districts growing sorghum during 1995-97, only 50 districts exhibited the mean yields more than national average (900 kg per ha). The remaining 83 districts fell in the category of less than $900 \mathrm{~kg}$ per ha. However, increased awareness and adoption of improved cultivars have changed the mean yield trends significantly at district-level during 2005-07. In a total of 151 districts growing sorghum in 200507, 87 districts demonstrated the mean yields of more than $900 \mathrm{~kg}$ per ha. The remaining 64 districts fell on the otherside of the coin.

\section{Factor responsible for yield gaps in kharif sorghum}

1. Low consumer preference as food crop, Kharif sorghum grain fetches low price in market.

2. Participation of private seed companies in seed production of Kharif sorghum hybrids is negligible since last half decade.

3. The grain yield affected due to grain mold incidence

4. Relative to sorghum, the net returns from the competing crops suitable grown in the same agro-ecology is much higher due to higher market price, hence sorghum remains neglected.

5. The weakening competitiveness of sorghum is also due to government policies being less favorable to sorghum, such as minimum support price (MSP) and absence of procurement of sorghum grain when the price falls in market below MSP.

6. Present Kharif sorghum hybrids and varieties are grown only for fodder purpose and less for grain purpose.

\section{Factor responsible for yield gaps in Rabi sorghum}

1. Less use of improved varieties.

2. More fodder preference (High population).

3. No or less use of chemical fertilizer.

4. Cultivated under residual moisture condition

5. Shoot fly \& aphid
6. Non adoption of In-situ moisture conservation practices

\section{Bridging yield gaps through}

- Supply of quality input supply

- Effective extension

- Improving agriculture Research \& extension interaction

- Promoting FFS by emphasizing skill transfer to staff as well as farmers

- Emphasizing Soil Health Programme

- Diversified farming which includes Horticulture, Dairy \& Animal Husbandry and Watershed infrastructure

Availability of post-harvest and processing infrastructure Government go down are available for storage of surplus produce for sorghum grain for medium storage period. For grains, basic cleaning and grading facilities are available in District Agriculture Marketing Committee which satisfies the need of local market for supply of quality grains to the consumers. Local farmer produce is mainly stored as house hold storage and surplus produce is sold at local markets. Fodder may be preserved as chaffed and silage but no such central Government or private facilities are available. Consumers satisfy their own need at small scale using chaff cutter or directly as farm or housed hold storages. As far as sorghum processing is concerned, majority of the processing is done as sorghum floor which is done at individual level. While for other processed products such as, biscuits, rawa, multigrain flour and biscuits an increasing interest and trend is observed in last few years. In future collaboration with private companies and cooperative sector may took a lead for such processed products and required infrastructures.

The existing policies of the government for minimum support price, procurement and distribution through public distribution systems

Till the year 2017-18 minimum support price for sorghum was very less (Rs 1620 / q). But net returns from both kharif and Rabi sorghum failed to cover the cost incurred for their cultivation and cost benefit ratio is also lower than their competing crops. However the Government of India have increased the MSP of kharif as well as Rabi sorghum up to the tune of Rs 2430 and Rs 2450 respectively during the year 2018-19. This will create active growth in the sorghum growing region of Maharashtra. As far as procurement of sorghum is concerned almost all grains are procured through local market and in District Market Committee and prices 
given for this produce may be lower than the government MSP. Due to this farmers are not growing kharif as well as Rabi sorghum on large area.

As rice, wheat and pulses are distributed through public distribution systems, these results in assured sell and remunerative price from these produce. Sorghum is not yet included in Public Distribution System, its inclusion may enhance the area under kharif as well as Rabi sorghum.

Development of diverse food dishes of millets grains to suit the need of various target groups

\section{a. Ready to eat products to be commercialized}

- Puffs from sorghum

It is the RTE (ready to eat) snack which is developed using puff gun machine. The puff gun machine is loaded with dehulled sorghum grain onto a rotating barrel and the mixture is roasted for and fired resulting in a puffed sorghum product.

$\begin{array}{ll}\text { Nutrients (100g) } & \text { Value } \\ \text { Protein }(\%) & 11.90 \\ \text { Fat }(\%) & 3.02 \\ \text { Dietary Fiber (g) } & 13.88\end{array}$

\section{- Extruded snacks}

Extruded Snacks are Ready-To-Eat products prepared using twin-screw hot extruder which combines heating with the act of extrusion to create a shaped cooked product through a round, minus shaped dies. The mixture is combined and passed through twin screw extruder to produce expanded snacks which are ready to eat. The snack can be coated with desired spices to create variations in the taste and flavor.

$\begin{array}{ll}\text { Nutrients (100g) } & \text { Value } \\ \text { Protein }(\%) & 12.90 \\ \text { Fat }(\%) & 1.70 \\ \text { Dietary Fiber }(\mathrm{g}) & 12.88\end{array}$

\section{- Instant mixes}

Instant sorghum idli mix, Instant upma mix, Instant dosa mix, Instant pongal mix, Sorghum muesli, Muesli is a product made by mixing of honey and dry fruits to sorghum flakes.

\section{b. Millets flour \\ c. Millets vermicelli}

Vermicelli is prepared using cold extrusion. This is very useful because of its low cost and continuous processing capability has been accepted as one of the most useful technologies during the recent years in the field of food processing.

\section{d. Bakery products}

Millets were incorporated indifferent variations from $10 \%$ to $50 \%$ levels to standardize cookies $(100 \%)$, bread/bun $(50 \%)$ and cake $(100 \%)$ by replacing refined wheat flour or using $100 \%$ millet flour at IIMR.

\section{- Millets cookies}

Cookies are popular ready-to-eat product consumed by different age groups in a family. Cookie of $100 \%$ millets is prepared using a planetary mixer, automatic cookie making machine and rotary oven.

- Millets bread/ bun

e. Value addition from by products

- By-product from flaking of sorghum: sorghum bran peda (sweet)

The by-product from flaking of sorghum is bran (seed-coat) powder and broken flakes. As sorghum bran and broken flakes are rich in fibre, iron and vitamin content it can be used to make various value added products. The value added products developed from the by-products are:

\section{f. Sorghum based energy bars}

The energy bar is one of the value added by-product made from bran and broken flakes during flaking of sorghum. The bran is finely powdered and dried to remove the moisture present in it. Along with bran and flakes, honey syrup was added as a binder and sweetener in formulating the product.

\section{g. Sorghum bran fryums}

The bran obtained after flaking of sorghum grain is collected and is boiled in water. Ingredients like Black gram dal flour, salt, green chilli paste, black pepper powder and baking soda are mixed in the mixture to prepare dough. Small quantity of dough is taken and filled in hand operated murukku making machine. Murukkus are made into 3-4 rounds as fryums and are dried under the sun.

\section{h. Bio-fortified and value added sorghum products}

(a) Zinc rich and Iron rich (Gingelly seed) Jowar: Jowar Biscuits and Vermicelli Zinc \& Iron rich (gingelly seed)

\section{Ready to eat products already commercialized Jowar atta}

Jowar rich multigrain atta, Jowar rawa (sorghum medium semolina), Jowar khichidi Rawa (sorghum coarse semolina, Jowar idli rawa, Jowar flakes

\section{Market linkages}

Sorghum is sold through both regulated and un-regulated channels. Regulated channels: Regulated markets are run in accordance with the rules and regulations framed by statutary market organization, agricultural produce market committee. Un-regulated channels: It includes sells to neighbours, family members, creditors and land lords. Sells at un-regulated village markets are known as shandies. Sorghum for food use is traded between major growing regions. The movement of sorghum for producer to consumer through various channels is given below:

Primary markets: Barshi, Jalna, Beed, Solapur

Secondary and Terminal market centres: Aurangabad, Pune, Mumbai, Latur, Parbhani, Kolhapur.

The produce of sorghum is generally retained for consumption and the surplus is sold locally in primary markets. The cleaned and graded produce in primary market is exported to terminal markets. Clean and graded grains is also sold under selected brand names e.g. Kohinoor, President, Gold coin in cities. 


\section{References}

1. Baavraj G, Parthsarathy Rao P, Basu K, Reddy Ch R, Ashok Kumar A, Srinivada Rao P, BVS Reddy. Assesing vaiability of Bio ethanol production from sweet sorghum. Working paper series no. 30, RP-MIP, ICRISAT, Patancheru 502 324, Andhra Pradesh 2012.

2. Basavraj G, Parthsarathy Rao P. Regional analysis of household consumption of sorghum in major sorghum producing and consuming states in India. Working paper series No. 28, RP-MIP, ICRISAT, Patancheru 502 324, Andhra Pradesh 2011.

3. Chand Ramesh. Demand for food grains. Economic and political weekly 2007;42(52):10-13.

4. Kumara Charyulu D, Cynthia Bantilan, Rajalaxmi A, BVS Reddy, Borikar A, Ashok Kumar A, Singh NP, Moses Shyam D. Development and diffusion of sorghum improved cultivars in India: Impact on growth and stability in yield. International Crop Research Institute for the semi-Arid Tropics 2014, P9.

5. Dayakar Rao B, Sitharama A, Suresh A, Sreekanth M, Reddy Nirmal K, Rao SV. Dynamics of value and trade channels of sorghum in India. Rajendra Nagar, Hyderabad 500030, Andhra Pradesh, India: Directorate of Sorghum Research 2010, P48.

6. Directorate of Economics and Statistics, Statitics at a Glance. New Delhi, Ministry of Agriculture, Government of India 2009.

7. Directorate of Millets Development Department of Agriculture, Co-operation \& Farmers Welfare, ministry of Agriculture \& Farmers Welfare, Government of India 2009.

8. Dry land cereal proposal, ICRISAT 2012.

9. Gopalan C, Ramasastri BV, Balasubramaniam SC. Nutritive value of Indian foods. National institute of nutrition, Indian Council of Medical Research, Hyderabad, India 1996.

10. Kleih Ulrich, Bala Ravi S, Dayakar Rao B. Industrial utilization of sorghum in India. Working Paper Series no. 4, Socioeconomics and Policy Program. Patancheru 502 324, Andhra Pradesh, India: International Crops Research Institute for the Semi-Arid Tropics 2000.

11. Hosmani MM, Chittapur BM. Sorghum Production Technology, University of Agricultural Sciences, Dharwad, India 1997. 